\title{
Assessing farm records-keeping behavior among small-scale pineapple farmers in the Nsawam Adoagyiri municipality, Ghana
}

\author{
S. A. MANTEAW*, B. W. AKPOTOSU, B. Y. FOLITSE \& S. MAHAMA \\ (S.A.M.: CSIR- Institute for Scientific and Technological Information (CSIR - INSTI); \\ B.W.A.: Department of Agriculture, Nsawam Adoagyiri Municipal Assembly, Nsawam; B.Y.F.: \\ Geospatial \& Information Science Division, CSIR - INSTI; S.M.: Council for Scientific and \\ Industrial Research Head Office, Accra) \\ *Corresponding author's email: smanteaw@yahoo.com
}

\begin{abstract}
This paper seeks to bring more clarity to the phenomenon of farm records keeping among small-scale pineapple farmers in the Nsawam Adoagyiri Municipality of the Eastern Region of Ghana. Specifically, it seeks to measure the motivation behind farm records keeping, the nature of records kept, the benefits derived from the activity and how demographic and socio-economic characteristics of farmers influence the practice. Using a multi-stage random selection procedure, 120 pineapple farmers selected from 25 pineapple growing communities in the Municipality were interviewed using structured interview schedules. The study showed that records keeping was common among the pineapple farmers interviewed with the farmers keeping at least six (6) farm records. The chi-square test showed that farm records keeping depended on educational level, years of experience in pineapple farming and farm size. Besides, records keeping was informed primarily by the desire to make productivity projections and promote effective agribusiness management. The study makes a strong case for sustained communication, education and awareness creation on the practice to engender good agribusiness outcomes.
\end{abstract}

Keywords: Farm records-keeping behavior, small-scale pineapple farmers, Nsawam Adoagyiri Municipality, Ghana

Original scientific paper. Received 01 Oct 2021; revised 26 Nov 2021

\section{Introduction}

Today's complex world economy and the rapid pace of the farming industry makes it difficult for producers to manage farm enterprises the way their parents did many years ago. It will not be far-fetched to assume that without a good understanding of records keeping with its current and future implications, farmers may not be able to make a good return on their investment in today's business environment. Comparatively, present-day farming operations may be becoming more and more business-oriented than yesterday's farm operations. Therefore, conceptually, this paper posits that being a successful farmer may be a function of one's ability to keep good quality records on a more consistent basis. This assumption is valid for all categories of crop farmers, including small-scale pineapple farmers, who are the subject of this paper.

Ghana Jnl Agric. Sci. 56 (2), 34 - 45

GJAS is an Open Access Journal and distributed under the terms of the Creative Commons (CC) License [CC BY 4.0] 
According to the FAO (2013), the world market for fresh pineapple expanded rapidly during the past years. Like other tropical fruits, pineapple is grown predominantly in developing countries, where two-thirds of rural people live on small-scale farms of less than two (2) hectares (Kleemann 2011). Pineapple (Ananas comosus (L) Merr.) is the most economically significant plant and the most developed horticultural crop in the Bromeliaceae family in Ghana (Bruce and Oku 2000; d'Eeckenbrugge and Leal, 2003). It is cultivated predominantly for its fruit that is consumed fresh or as canned fruit and juice. The contribution of pineapple to the economy of Ghana has been immense. Pineapple production creates employment and, hence, a source of income for thousands of people ranging from farmers to market women.

The establishment of factories for the processing of pineapple at Bawjiase (Central Region), Asamankese, Nsawam, Adeiso (Eastern Region), Tema and Accra (Greater Accra Region), Ho and Tafe in the Volta Region, is a boost for cottage industrialisation (MoFA, 2006; Central Regional Development Commission, 2006). Therefore, pineapple is an essential non-traditional export crop in Ghana and, hence, a source of foreign exchange earnings. In 2012 for instance, US $\$ 16,816,000$ was realised from the export of 41,212 metric tonnes (MoFA, 2013). Access to international markets, enhanced value of fresh fruits, resuscitation of pineapple cultivation and local processing have recently encouraged the development of a few large-scale farms where pineapple is produced as a mono-crop (Adesope, Awoyinka, and Babalola, 2009).

Since, pineapple production is a fastgrowing agricultural business in Ghana, the profitable production of the crop is essential. Therefore, this study is informed by the desire to contribute to introducing business principles in the cultivation of the harvest to enhance its productivity.

According to Dudafa (2013), most farmers do not attach a great deal of importance to records keeping in their farming operations. They often talk of profit and loss not based on facts and figures derived from record books, but from intuition or guessing. This failure to keep records in the view of Dudafa (2013), results in part from the subsistent nature of production and the educational background of the farming communities. Although, most crucial information is committed to memory from year to year, this practice may not be the best.

Being solely a good farmer may no longer be good enough to remain in business. The key to becoming a successful farmer today requires being a good farm producer and financial manager as well. Therefore, it may not be entirely wrong to assume that the first step to being a successful farm manager is keeping good, accurate and consistent records and establishing a sound records-keeping system. There is a misconception that the only reason a person needs records is to report on taxes. However, records keeping plays a much larger role in business. Farming is a business and documents can help plan improvements for that business, and make proper management decisions (Hartsfield, 2012).

According to Winkler (2008), farm records are essential tools in farm management. However in Africa, where it is estimated that about $42 \%$ are still illiterate (Christiaensen, 2016), farmers are still generally unwilling to enlist the services of clerks and rather rely to a large extent on mental records keeping. Nevertheless, there is a need to encourage the documentation even at the small-scale farmer level of all activities on the farm and the expenses and the returns in physical and monetary terms within the framework of the general farmer education programme. Kayode 
(2002), also noted that records were are active process of decision-making in planning, organising, directing, coordinating, controlling and motivating farm management. Similarly, Armstrong (2002) proved that farm records were essential economic characters as they were concerned with the effective attainment of chosen, accepted objectives through the optimal use of resources. Abel (2000) much earlier also identified farm records as an economic, sociological, psychological, mathematical, statistical, logical and practical science.

There are various types of farm records, but Omoruyi, Orhue, Akerobo and Aghimien (1999) and Poggio (2006) classified farm records under four (4) basic types, namely resource inventories, production records, financial records, and supplementary records. Resource inventories include assets and liabilities of the farm, while production records include everything that is produced on the farm and labor use. Financial records include income from the sale of farm produce, chemicals and maintenance of farm equipment. Supplementary records include the survey map, the farm layout (map) and the legal documents of the farm. Most farmers appear to be more concerned about the productivity of their farm business and, therefore, may keep only production records. In two separate earlier studies by Devonish et al. (2000) and Okantah et al. (2003), revealed that the majority of farmers $(76 \%$ and $95 \%)$ kept financial records respectively. These show the importance farmers attach to their financial needs.

Farm records keeping is a key practice used by very successful farmers (Muhammad et al., 2004). Accurately written farm records are beneficial. Chapman (2003) and Iton (1999) noted that a farmer who has a wellkept farm record is better positioned to borrow funds than one who has no farm records. This assertion was further established by Devonish et al. (2000) that more than half (57\%) of a total of 160 farmers interviewed obtained credit because they kept farm records. Farm records may therefore be a precursor to obtaining farm credit. However, the $43 \%$ who were not getting farm credit did not keep farm records. Johl and Kapur (2001) also stated that when farmers keep records, they continuously give the needed information for state and national farm policies such as land and price policies. Farm records keeping helps in research works, which require precise and correct data.

Keeping farm records is affected by certain factors. According to Mariene (1995) and Devonish, Pemberton, \& Ragbir (2000), farm records keeping is independent of age, gender, farm size, level of formal education, and years of farming experience. The research by Devonish et al. (2000), further showed a significant relationship between farm records keeping and the following factors: farmer status, the receipt of credit, and net income. Poggio (2006) indicated that farm record keeping is often seen as a routine duty for farmers. Farmers are faced with challenges that prevent them from keeping farm records. Notably among the obstacles is illiteracy, as noted by Minae, Baker \& Dixon (2003).

Similarly, low numeracy levels in most low-resource African farming communities are a challenge (Tham-Agyekum et al., 2010). Another challenge that confronts farmers is that, most of them engage in multiple farming enterprises and mixed farming systems, and thus farm records keeping requires much of their time. They are, therefore, challenged with time which deters them from keeping farm records (Johl and Kapur 2001). The subsistence nature of farming in our world does not produce any incentive for keeping farm records (Johl and Kapur 2001). Singh (2001), similarly commented that small-scale farmers know that because of the sizes of their farm holdings, they 
will not be able to affect economies of scale; therefore, do not show interest in farm records keeping.

According to Minae (2001), a lack of sensitization on the importance of farm records keeping on the performance of farm businesses by extension agents is a challenge that cannot be overlooked. However, not much research has been conducted on this culture of records keeping in Ghana in general, and in the Nsawam Adoagyiri Municipal Assembly among smallscale pineapple farmers. Consequently, not much is known about the nature and scope of farm records keeping among the pineapple farmers in the area. This study, therefore, seeks to contribute to the intellectual discourse concerning the behavior of farm records keeping as it relates to small-scale pineapple farmers in the Nsawam Adoagyiri Municipality of the Eastern Region of Ghana. Specifically, it seeks to examine the motivation behind farm records keeping, the various types of records kept by the farmers, the benefits derived from the practice, coupled with the challenges as well as ways in which demographic and socio-economic characteristics of the farmers influence the practice.

Apart from giving some useful insights into the types of records kept and the methods used to keep records, this study would engender a better understanding and appreciation of the challenges related to records keeping. This would help stimulate well-informed education and sensitization of the practice among farmers in the Municipality. Information gained from this study would inform policy, feed into the agricultural extension activities in the Municipality, and shape the quality of extension delivery generally in Ghana.

\section{Materials and Methods}

Study Area

The study area was the Nsawam Adoagyiri Municipality in the Eastern Region of Ghana. The Nsawam Adoagyiri Municipality is well noted for the high production of Ghanaian pineapple due to its climatic conditions and proximity to the airport and harbour for export (Ninson, 2012). Per information accessed on its website, the Municipality comprises the Densu Plains, the Pompan narrow land and the Akuapim Togo mountain range, which rises over 1000 feet above sea-level at Aburi. Again, the Municipality is drained by the Densu River and its tributary rivers and streams. The Densu itself is approximately $115.8 \mathrm{~km}$ long, and its source is the Atiwa mountain ranges near Kibi in the Eastern Region. The Municipality is covered by two (2) main vegetation types, the moist semi-deciduous forest, and coastal savannah grassland. The forest occupies almost $90 \%$ of the municipal, covering the north, west and all of the area in the east. The remaining $10 \%$ is to the south where coastal shrub and grassland vegetation dominates. This forms the transitional zone between the coastal savannah and rain forest regions. Agricultural activities in the Municipality Centre mainly on nontraditional crops, such as pineapples, papaw, pepper, garden eggs and sunflower, cultivated mainly for export. This means lots of potential for export earnings accruable to investors. Pineapple, the leading crop produced in the Municipality accounted for some $60 \%$ of total national pineapple export earnings.

\section{The population of the study}

The population for the study was made up of all small-scale pineapple farmers in the Municipality. The Municipal Directorate of 
the Ministry of Food and Agriculture was consulted to obtain background information about the pineapple farmers in the Municipality and a list of the small-scale pineapple farmers in the Municipality.

\section{Sampling procedure}

A multi-stage random selection procedure was followed to select the respondents for the study. Per data from the Municipal Department of Agriculture, a total of 25 communities with a population of 3,590 farmers in the Municipality produce pineapples for export and the local market. Out of these, 12 communities were randomly selected for the study. These communities were Ankwa Dobro, Panpanso, Sakyikrom, Krokese, Akraman, Bowkrom, Daaman, Oparekrom, Nkyenenkyene, Fotobi, Djankrom and Akuffokrom. Similarly, ten (10) farmers were randomly selected based on a database obtained from the Department of Agriculture from each community and interviewed for data gathering. The sample population for the study was 120 pineapple farmers.

\section{Data collection and analysis}

A quantitative approach through the use of personal interview schedules was employed to collect data from key pineapple farmers. Data were collected on demographic characteristics, various types of farm records kept by pineapple farmers, the benefits of keeping farm records and the challenges faced by pineapple farmers in farm records keeping. The data were analysed using the Statistical Package for Social Sciences (SPSS) version 21. Data were further presented in tables, graphs, and Chi-square analyses, which gave a condensed picture of the records-keeping behavior of the pineapple farmers in the study area. All field data for the purposes of this research was collected in the 2019.

\section{Results and Discussion}

Respondents' demographic and socioeconomic characteristics

According to Table 1, male pineapple farmers represent $90.8 \%$, while females represent $9.2 \%$. The results showed that female pineapple farmers have a low representation in the pineapple industry in the Municipal Assembly; a fact corroborated by Baah (2017). This may be attributed to the laborious nature of pineapple farming, which may be unattractive to females. Assassie (2008) observed that women might go into farming to meet demands at home. He further explained that gender has proven to be an essential variable for analyzing roles, responsibilities, constraints, opportunities, incentives, costs and benefits in agriculture. The mean age of the Pineapple farmers in the study area was 46.54 years. The results showed that most pineapple farmers were in their active years as over $60 \%$ were below the age of 50 . This finding runs contrary to the conclusion contained in the Report by Henriques (2019) for the $\mathrm{BBC}$, which noted that the rapid ageing of the farm work-force was an indication of dislike among the youth for agricultural work.

The results also showed that majority of the pineapple farmers in the study area were literates. The engagement of educated people in farming is an asset to extension services to sustain the pineapple business. Education may polish an individual, develop the intellect and make a person a vast user of resources. Educated people are more likely to be exposed and may avail themselves of information. Several researchers had argued the effect of education on adoption. For instance, in separate studies (Voh, 2002) reported a positive and significant relationship between formal education and the use of agricultural extension services. Table 1 further showed that the mean number of years of pineapple production in the study area was 18 years. This showed that most of the respondents might be in pineapple production due to its economic importance. 
TABLE 1

Demographic Characteristics of Small Scale Pineapple Farmers in the Nsawam Adoagyiri Municipal Assembly

\begin{tabular}{lcccc}
\multicolumn{5}{c}{ Nsawam Adoagyiri Municipal Assembly } \\
Sex & Frequency & Percentage & SD & Mean \\
Male & 109 & 90.8 & & \\
Female & 11 & 9.2 & & \\
Age & & & & \\
$20-29$ & 4 & 3.3 & & \\
$30-39$ & 24 & 20.0 & 19.65 & 46.54 \\
$40-49$ & 46 & 38.3 & & \\
$50-59$ & 30 & 25.0 & & \\
$60-69$ & 16 & 13.3 & &
\end{tabular}

Educational level

Non-Forma

$4 \quad 3.3$

Primary School

32

26.7

Mid Sch/JHS

47

39.2

Secondary School

23

19.2

Tertiary Education

14

11.7

\section{Marital Status}

Married

Single

12

10.0

\section{Household Size}

2-3

4-5

6-7

$8-9$

Number of Years in farming

$1-10$

11-20
20

8

54

39

19

58
6.7

45.0

1.53

5.75

32.5

15.8

16.7

48.3

7.69

18.82 


$\begin{array}{ccc}21-30 & 34 & 28.3 \\ 31-40 & 8 & 6.7\end{array}$

\section{Farm size}

1-5 Hectares

106

88.3

5-10 Hectare

10

8.3

8.45

$20+$ Hectares

4

3.3

Type of Farm Records kept by Small Scale

Pineapple farmers in the Municipality

Pineapple farmers are largely innovative and would be expected to introduce business principles in their farming operations. A comparative study of the cocoa and pineapple value chains in Ghana by Manteaw, Anaglo \& Boateng (2015), concluded that pineapple farmers by virtue of the nature of the industry, were more innovative than cocoa farmers. The study showed that farm records keeping was a common practice among the pineapple farmers in the study area, with farmers keeping six (6) categories of farm records. Results from Table 2 indicated that, $98.3 \%$ of the pineapple farmers in the Municipality kept records of customers who bought from them at the farm gate price. Similarly, $97.5 \%$ of the pineapple farmers kept records on production activities, while $94.2 \%$ indicated that, they kept records of sales on a daily basis during harvesting. It was also revealed that, $90.8 \%$ of the pineapple farmers kept financial records, while $83.3 \%$ kept records on labour engaged during the farming activities. Almost a third of the pineapple farmer population in the study area kept farm inventory records. The study also showed that, pineapple farmers in the Nsawam Adoagyiri
Municipal Assembly kept various types of farm records to enable them to improve upon their farming activities.

TABLE 2

Type of farm Records

\begin{tabular}{lcc}
\hline Type of Records & Frequency & Percentage \\
\hline Customer record & 118 & 98.3 \\
Production record & 117 & 97.5 \\
Sales record & 113 & 94.2 \\
Financial record & 109 & 90.8 \\
Labour record & 100 & 83.3 \\
Farm inventory & 67 & 55.8 \\
\hline
\end{tabular}

Keeping of Farm Records

As shown in Fig. 1, 63.3\% of the pineapple farmers in the Municipality preferred to keep their farm records daily. In comparison, 33.3\% preferred keeping farm records every week and $3.3 \%$ kept their farm records monthly. These results agree with Okantah et al. (2003) who noted that, the main reason behind the highest percentage of farmers keeping their records on a daily basis was that, farmers needed to keep track of activities on the farm daily. However, Devonish et al. (2000) concluded that most of the farmers (38\%) preferred to record their data weekly in Barbados, which was largely not in consonance with this study. 




Fig 1: Frequency of farm records keeping by pineapple farmers

\section{Storage of Farm Records}

While the majority of pineapple farmers $(83.3 \%)$ in the Nsawam Adoagyiri Municipal Assembly kept their farm records manually, either in books, on sheets of papers, on notice boards in the office, on walls to be transferred later into record books, $12.5 \%$ adopted the computerized system only using mainly Microsoft Office Excel. However, $4.1 \%$ of the pineapple farmers in the Municipality used both systems (manual and computerized) to store their records. The result confirmed Tham-Agyekum et al. (2010) that the majority of small-scale poultry farmers in the Ga East Municipality kept their records manually. These findings have implications for the drive towards digitization and the deployment of ICT tools in farm activities for the needed efficiency.

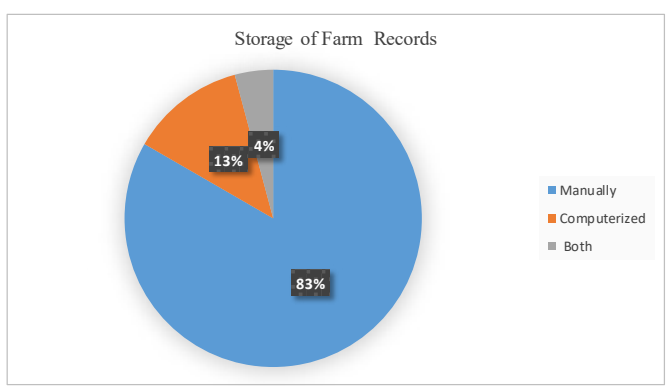

Fig 2: Storage of Farm Records

\section{Demographic and Socio-economic Factors} Affecting Farm Records Keeping

Results in Table 3 showed the Chi-square analysis of demographic and socio-economic factors affecting small-scale pineapple farmers' records in the study area. The demographic characteristics were age, sex, education level and marital status, while the socio-economic factors tested were: household size, years of experience and farm size. All factors were tested at a 5\% level of significance. The results showed a positive relationship between the education level of pineapple farmers ( $p$ $=0.000)$ and record keeping. This positive implication highlights that as more educated farmers are able to read, write and comprehend the importance of records keeping in the farm business, they are more likely to keep records. Farm records keeping was also dependent on farming experience $(p=0.000)$. The farming experience was positively related to records keeping; this implies that, the more experience a farmer has, the more likely that a farmer will keep records. Farm size $(p=0.000)$ was directly related to records keeping; the larger the farm size, the more likely the farmer would keep records. The results of the chi-square analysis continue to affirm that farm records keeping is an important practice in the farm business and the pineapple farmers are not oblivious of this fact.

TABLE 3

Chi-square analysis of Demographic and Socioeconomic factors affecting farm records keeping of Small Scale Pineapple farmers

\begin{tabular}{lccc}
\hline Variable & $\boldsymbol{X}^{2}$-value & Df & p-value \\
\hline Sex & 9.995 & 4 & 0.061 \\
Age & 8.273 & 80 & 0.238 \\
Educational level & 82.938 & 16 & \\
Marital status & 5.115 & 4 & 0.276 \\
Household size & 3.476 & 28 & 0.284 \\
Years of Experience & 367.322 & 68 & \\
Farm size & 129.441 & 36 & \\
\hline
\end{tabular}

Note $=*$ Significant statistically at $0.05, \chi^{2}$ chi-square value 


\section{Benefits of Keeping Farm Records by Pineapple} Farmers

Farm records keeping is an important part of farming. The records have to be accurate and up-to-date reflecting on all activities that occur on the farm. By the preceding findings, pineapple farmers in the Nsawam Adoagyiri Municipality have largely endorsed the importance of farm records. Table 4 showed that, $98.3 \%$ of the pineapple farmers agreed that keeping farm records enabled them to make productivity projections; $97.5 \%$ also indicated that farm records would help manage change and improvements in the agribusiness. Similarly, $96.76 \%$ of the pineapple farmers established that farm records would provide an accurate picture of their farm operations. In comparison, $95.8 \%$ revealed that farm records would measure the efficiency and progress of the agribusiness. Additionally, $94.1 \%$ of the pineapple farmers maintained that, farm records would help farmers identify strengths and weaknesses in the farm business. In comparison, $93.3 \%$ recognised that, keeping farm records would make it easy for a farmer to give information/data about the farm operations when asked. About the financial position of the farms, $74.1 \%$ of the pineapple farmers admitted that keeping farm records would allow one to know about the financial situation of the farms. This is not surprising as these results confirm the earlier assertion of Johl \& Kapur (2001), who stated that for fear of imposing taxes may not be amenable to maintaining farm records.

TABLE 4

Benefits of keeping a record

\begin{tabular}{lcc}
\hline Benefits & Frequency & Percentage \\
\hline $\begin{array}{l}\text { Make productivity } \\
\text { projections }\end{array}$ & 118 & 98.3 \\
$\begin{array}{l}\text { Help manage changes } \\
\text { and improvements in } \\
\text { the agribusiness }\end{array}$ & 117 & 97.5
\end{tabular}

\begin{tabular}{lcc}
$\begin{array}{l}\text { Provide an accurate } \\
\text { picture of your farm } \\
\text { operations }\end{array}$ & 116 & 96.6 \\
$\begin{array}{l}\text { Measure efficien- } \\
\text { cy and progress. }\end{array}$ & 115 & 95.8 \\
$\begin{array}{l}\text { Identify } \\
\text { strengths and } \\
\text { weaknesses in } \\
\text { the farm busi- } \\
\text { ness. }\end{array}$ & 113 & 94.1 \\
$\begin{array}{l}\text { Easy to give informa- } \\
\text { tion/data when asked }\end{array}$ & 112 & \\
$\begin{array}{l}\text { Know about the } \\
\text { financial position of }\end{array}$ & 89 & \\
your farm & & \\
\hline
\end{tabular}

Challenges of Keeping Farm Records Poggio (2006) observed that, farm records keeping is often seen as a routine duty by farmers; however, small-scale pineapple farmers in the Municipality encounter some challenges in keeping records. Table 5 showed that for $41.7 \%$ of the farmers, the lack of formal training in records keeping was a key challenge. The result confirmed the earlier findings by Minae et al. (2003), who noted that the lack of keeping farm records was more pronounced because of the high levels of illiteracy and low numeracy levels in resourcepoor African farming communities. Similarly, $26.7 \%$ indicated that their inability to keep farm records was due to time constraints, a finding consistent with the assertion of Johl \& Kapur (2001) that farmers were faced with time constraints which served as a disincentive to keeping farm records. On the other hand, $17.5 \%$ of the pineapple farmers said their inability to enter data into record books on account of stress, served as a deterrent to keeping farm records. Although only mentioned by $14.1 \%$, the last challenge had to do with the real or perceived fear of officials of the Internal Revenue Service of the Ghana Revenue Authority invading their premises to inspect their tax obligations. 
TABLE 5

Challenges of keeping farm records

\begin{tabular}{lcc}
\hline $\begin{array}{l}\text { Problems of keep- } \\
\text { ing a record }\end{array}$ & Frequency & Percentage \\
\hline $\begin{array}{l}\text { Have no formal } \\
\text { training in record }\end{array}$ & 50 & 41.7 \\
keeping & & \\
Time constraints & 32 & 26.7 \\
$\begin{array}{l}\text { Difficulty in enter- } \\
\text { ing data into record } \\
\text { books due to stress }\end{array}$ & 21 & 17.5 \\
$\begin{array}{l}\text { Have high tax as- } \\
\text { sessment if records } \\
\text { are kept }\end{array}$ & 17 & \\
\hline Total & & 14.1 \\
\hline
\end{tabular}

\section{Conclusion and Recommendation}

This study has shown that keeping farm records is common practice among the pineapple farmers in the Nsawam Adoagyiri Municipal Assembly in the Eastern Region of Ghana, with all the farmers interviewed keeping at least six (6) categories of farm records. Regarding the frequency of records keeping, the farmers kept daily, weekly and monthly records, while farm records were kept manually, computerized or both. The Chi-square analysis showed that a positive relationship between records keeping and factors such as the educational level of farmers, their farming experience and their farm sizes. Some of the benefits cited by the farmers as motivation for keeping farm records included the ability to make productivity projections, managing changes and improvements in agribusiness, providing an accurate picture of farm operations, identifying strengths and weaknesses in the farming business and making responses to inquiries much easier. Some of the challenges that served as a disincentive to records keeping from the perspectives of the farmers included the lack of formal training in the practice of records keeping; the limitation of time; and the real or perceived fear of officials of the Internal Revenue Service of the Ghana
Revenue Authority invading their premises to inspect their tax obligations.

There are important lessons to be learnt from the findings of this study, which have implications for policy and practice. First, if the introduction of business principles in farming is anything to go by, then the culture of records keeping should be promoted in the agricultural extension activities in the Municipality in particular and the country as a whole. Secondly, the success story of the pineapple farmers as it relates to records keeping ought to be shared with other commodity farmers to stimulate the practice among all categories of small-scale farmers. Thirdly, the policy direction ought to be on a strong case for sustained communication, education and awareness creation on the proper farm record -keeping practice to engender good agribusiness outcomes.

\section{REFERENCES}

Abel, C. (2000) Farm management in West Africa. Ogunle Publishers, Ogun State, Nigeria.

Adesope, A. A. A., Awoyinka, Y. A. \& Babalola, D. A. (2009) Economic analysis of groupmarketing of pineapples in selected markets of Osun state, Nigeria. ACTA SATECH Journal of life and Physical Sciences. 3 (1): 47-52.

Armstrong, C. J. (2002) Farmers' perception about farm records. Alberters Press, Abeokuta, Nigeria.

Assassie, L. K. (2008) Effectiveness of teaching and learning in the agricultural colleges as perceived by stakeholders in the Ashanti region of Ghana. Kwame Nkrumah University of Science and Technology (KNUST), Kumasi - Unpublished undergraduate thesis.

Baah, P. A. (2017) Global GAP standard compliance and profitability: a case study of smallholder pineapple farmers in Akuapem-South of Ghana. International 
Journal of Agricultural Management and Development 7 (2), 165-177.

Bruce, P. A. M. \& Oku, S. (2000) Survey on non traditional crops in Ghana. Ministry of Agriculture, Policy Planning Monitoring and Evaluation Directorate, Accra.

Central Regional Development Commission (2006) Investment opportunities: fishing, pineapple and cashew, oil palm and cassava. p 2. Cape Coast: CEDECOM.

Chapman, M. E. N. (2003) Keeping farm records in Sudan. Historical Document, Kansas Agricultural Experiment Station, Available at: www.oznet.ksu.edu, retrieved on 4th November, 2019.

Christiaensen, L. (2016) Poverty in a rising Africa. World Bank Blog, published March 2016.

D'eeckenbrugge, G, C. \& Leal, F. (2003) Morphology, anatomy, and taxonomy. In D. P. Bartholomew, R. E. Paull, and K.G. Rohrbach. The Pineapple: Botany, Production, and Uses. p. 21, CABI Publishing: Wallingford, UK.

Devonish, E., Pemberton C. A. \& Ragbir, S. (2000) Record keeping among small farmers in Barbados. Department of Agricultural Economics and Extension, University of the West Indies, St Augustine, Trinidad and Tobago.

Dudafa, U. J. (2013) Record keeping among small farmers in Nigeria: problems and prospects. International Journal of Scientific Research in Education, 6 (2), 214-220.

FAO (2013) Analysis of trade impacts on the fresh pineapple sector in Ghana. FAO Commodity And Trade Policy Research Working Paper No. 41, compiled by Julius Gatune, Mitchris Chapman-Kodam, Kwesi Korboe, Francis Mullangu and Manitra A. Rakotoarisoa.

Hartsfield, J. (2012) The Importance of keeping good farm records. [online] $\mathrm{NC}$ Cooperative
Extension. Available at: https://sampson. ces.ncsu.edu/2012/07/theimportance-ofkeeping-good-farm-records-4/ (Accessed 14 Jan. 2019).

Henriques, M. (2019) Follow the Food: The ageing crisis threatening farming. Publication by the British Broadcasting Corporation in Association with Corteva.

Iton, A. (1999) Small farmer participation in export targeting production in the $\mathrm{W}$ i n d w a r d Islands. OECS/EDU, Roseau, Dominica.

Johl, S. S., \& Kapur, T.R. (2001) Fundamentals of farm business management pp. 253-259. Kalyani Publishers.

Kayode, B. A. (2002) Farm records and statistics. Alvaton Press, Ibadan, Nigeria.

Kleemann, L. (2011) Organic pineapple farming in Ghana - a good choice for smallholders. Kiel Working Paper No. 1671. Kiel Institute for the World Economy, Hindenburgufer 66, 24105 Kiel, Germany.

Manteaw, S. A., Anaglo, J. N., \& Boateng, S. D. (2015) The dynamics of linkages and innovativeness in publicly and privately driven agricultural value chains. Journal of Agricultural Extension 19 (1), 1-23, 2015.

Minae, S. (2001) El sector forestal en el tercer milenio en Cost Rica (Translated: The forestry sector in the third millennium in Cost Rica). San Jose, Costa Rica.

Minae, S., Baker, D. \& Dixon, J. (2003) Status of farm data systems and farmer decision: Support in Sub-Saharan Africa: FAO, Rome, 2008.

Ministry of Food and Agriculture (2006) Agriculture in Ghana - Facts and Figures pp. 36. Statistics, Research and Information Directorate (SRID) of Ministry of Food and Agriculture. Accra, Ghana.

Ministry of Food and Agriculture (2013) Agriculture in Ghana Facts and Figures pp. 65. Statistics, Research and Information 
Directorate (SRID) of Ministry of Food and Agriculture Accra: Ghana.

Muhammad, S., Tegegne, F. \& Ekanem, E. (2004) Factors contributing to success of small farm operations in Tennessee. Journal of Extension Vol. 42 (4). Institute of Agricultural and Environmental Research, Tennessee State University Nashville, Tennessee.

Ninson D. (2012) Analysis of pineapple production in the Akwapim South municipal area. An unpublished thesis submitted to the Department of Agricultural Economics and Agribusiness, College of Agriculture and Consumer Sciences, University of Ghana, Legon.

Okantah, S. A., Aboe, P. A. T., Boa-Amponsem, K., Dorward, P. T. \& Bryant, M. J. (2003) Small-scale chicken keeping in perurban Accra and Kumasi. Final Technical Report of United Kingdom Department for International Development (DFID)-funded Project 74. DFID. R7631, Livestock Production Research Programme.
Omoruyi, S. A., Orhue, U. X., Akerobo A. A. \& Aghimien C. I. (1999) Prescribed Agricultural Science for Senior Secondary Schools, Revised Edition. Idodo Umeh Publishers Limited, Benin City.

Poggio, M. (2006) Farm Management Records. Available: www.srdc.gov.au, retrieved on 4th November, 2017.

Tham-Agyekum, E. K., Appiah, P. \& Nimoh, F. (2010) Assessing farm record keeping behavior among small-scale poultry farmers in the Ga East Municipality. Journal of Agricultural Science Vol. 2, No. 4.

Voh, J. P. (2002) Information sources and awareness of selected recommended farm practices: A case study of Kaduna State, Nigeria. African Journal of Agricultural Science Vol 8, No. 1 \& 2, pp. 87.

Winkler, M. M. (2008) Farm accounting from the viewpoint of the farmer manager. Journal of the American Society of Farm Managers and Rural Appraisers, Vol. 2, pp. 27. 